\title{
Psychometric Properties of Turkish Compass of Shame Scale
}

\section{Utanç Pusulası Ölçeği Türkçe Formunun Psikometrik Özellikleri}

\author{
İrem Akınc1 ${ }^{1}$ [) , Merve Cesur Atintaș ${ }^{1}$ (])
}

'Res. Assist. Dr., Ankara University, Faculty of Language, History and Geography, Department of Psychology, Ankara, Turkey

ORCID: I.A. 0000-0002-3093-9591; M.C.A. 0000-0002-0275-0097

\section{Corresponding author/Sorumlu yazar:} Merve Cesur Atintaş, Ankara University, Faculty of Language, History and Geography, Department of Psychology, Ankara, Turkey

E-mail/E-posta: cesurmerve2@gmail.com

Submitted/Başvuru: 22.07.2019 Revision Requested/Revizyon Talebi: 14.11.2019

Last Revision Received/Son Revizyon:

31.01.2020

Accepted/Kabul: 07.02.2020

Published Online/Online Yayın: 13.11.2020

Citation/Atıf: Akinci, I. \& Cesur Atintas, M. (2020). Psychometric properties of Turkish compass of Shame scale. Psikoloji Çalışmaları - Studies in Psychology, 40(2): 361-383. https://doi.org/10.26650/SP2019-0053

\begin{abstract}
The Compass of Shame Scale (CoSS) was developed to measure the ways individuals deal with shame. The scale consists of 48 items and four factors (withdrawal, attack other, attack-self, avoidance). This study aimed to investigate the psychometric properties of the Compass of Shame Scale (CoSS) in a Turkish sample. The sample consisted of 496 adults (137 male, 359 female) aged between 18 and 66 years. The data for test-retest analysis were collected from 76 participants two weeks after the first measurement. Participants were asked to complete the Compass of Shame Scale, Trait Shame and Guilt Scale, Trait Anger and Anger Expressions Inventory, Difficulties in Emotion Regulation Scale, Beck Depression Inventory, and a Demographic Form. In order to test the construct validity of CoSS an exploratory factor analysis (EFA) with varimax rotation was conducted and its correlations with theoretically similar constructs were tested. The results of the factor analysis were compatible with the fourfactor structure of the original scale. Regarding correlations, withdrawal, attack self, and attack other showed significant correlations with trait shame, anger, anger expressions, difficulties in emotion regulation, and depressive symptoms. Avoidance, however, had small but significant correlations with pride, anger, and internalized anger. These findings support the construct validity of the scale. The Cronbach's alpha values for the internal consistency reliabilities of the factors were estimated and ranged between .71 and .89 . The values calculated for testretest reliability ranged from .71 to .80 . In addition, significant gender differences were found for the withdrawal and attack self factors such that women scored significantly higher than men in these factors. These findings provided strong evidence for the reliability and validity of the Turkish CoSS.
\end{abstract}

Keywords: Shame, coping, validity, reliability, Compass of Shame Scale 


\section{ÖZ}

Utanç Pusulası Ölçeği (UPÖ), bireylerin utançla baş etme biçimlerini ölçmek amacıyla geliştirilmiş bir ölçektir. Ölçek 48 madde ile dört faktörden (geri çekilme, başkalarına saldırma, kendine saldırma, kaçınma) oluşmaktadır. Bu çalışmada UPÖ’nün psikometrik özelliklerinin Türkiye örnekleminde incelenmesi amaçlanmıştır. Çalışma örneklemi, yaşları 18 ile 66 arasında değişen 496 yetişkinden (137 erkek, 359 kadın) oluşmaktadır. Test-tekrar test güvenirliği için ilk ölçümden iki hafta sonra 76 katılımcıdan tekrar ölçüm alınmıştır. Katılımcılardan Utanç Pusulası Ölçeği, Sürekli Utanç ve Suçluluk Ölçeği, Sürekli Öfke ve Öfke İfadeleri Envanteri, Duygu Düzenleme Güçlüğü Ölçeği, Beck Depresyon Envanteri ve Demografik Form doldurmaları istenmiştir. UPÖ’nün yapı geçerliğini incelemek için varimax rotasyonlu açımlayıcı faktör analizi yapılmış ve teorik olarak ilişkili diğer yapılarla olan korelasyonları test edilmiştir. Faktör analizi sonuçları, orijinal ölçeğe benzer şekilde dört faktörlü bir yapı ortaya koymuştur. Korelasyon analizi sonuçlarına göre ise, UPÖ’nün kendine saldırma, başkalarına saldırma ve geri çekilme faktörleri sürekli utanç ve öfke, öfke ifade tarzları, duygu düzenleme güçlükleri ve depresif belirtiler ile anlamlı korelasyonlar göstermiştir. Kaçınma faktörü ise gurur, öfke ve bastırılmış öfke ile düşük ancak anlamlı düzeyde ilişki göstermiştir. Bu bulgular ölçeğin yapı geçerliğini destekler niteliktedir. Ölçeğin iç tutarlılık güvenirliğini test etmek amacıyla faktörlere ait Cronbach alpha katsayıları hesaplanmış ve katsayıların .71 ile .89 arasında değiştiği görülmüştür. Test-tekrar test güvenirliği için hesaplanan değerler .71 ile .80 arasında değişkenlik göstermektedir. Ayrıca, geri çekilme ve kendine saldırma faktörleri için anlamlı cinsiyet farklılıkları tespit edilmiş, bu faktörlerde kadınların erkeklerden anlamlı olarak daha yüksek puan aldıkları bulunmuştur. Tüm bu bulgular, Utanç Pusulası Ölçeği’nin Türkçe versiyonunun, geçerlik ve güvenirliğine dair güçlü kanıtlar sunmaktadır.

Anahtar Kelimeler: Utanç, başa çıkma, geçerlik, güvenirlik, Utanç Pusulası Ölçeği 
Shame is one of the self-conscious emotions, emerging around two years of age and requiring an awareness of self, others, and societal norms as well as an evaluation of one's own behavior according to these norms (Lewis, 1995). As with the other self-conscious emotions, shame organizes our interpersonal relations and helps us to detect socially inappropriate behaviors (Tangney \& Tracy, 2012). Turkish culture has a collectivistic structure in which the social image, represented mostly through the honor concept, is at the forefront for individuals (Uskul et al., 2014). In honor cultures, shame has an important function in protecting one's honor (Boiger, Güngör, Karasawa, \& Mesquita, 2014). For instance, it was found that in an honor culture, shame motivated individuals to verbally defend themselves against the one who had insulted them, while in non-honor cultures shame triggered individuals to withdraw in the face of the same act (Mosquera, Fischer, Manstead, \& Zaalberg, 2008). A recent review indicated that shame and guilt are culturally sensitive emotions and need to be studied culture specifically (Söylemez, Koyuncu, \& Amado, 2018). Thus, understanding responses to shame in a collectivistic context is important in order to examine the behaviors it motivates. Gender also makes a difference in shame coping styles of individuals (Elison, Pulos, \& Lennon, 2006). Considering culture specific gender socialization practices, it would be important to investigate shame coping styles of men and women in a collectivistic context. In addition to the culture and gender specific aspects, shame, as an intense emotion, is related to diverse psychopathologies and the type of psychological symptoms can change depending on how individuals cope with shame (Elison, Pulos \& Lennon, 2006). Shame coping styles of individuals are also influential in psychotherapeutic contexts (i.e., supervision and psychotherapy) (Black, Curran, \& Dyer, 2013; Hahn, 2001). It is important for clinicians to detect the characteristic ways that individuals cope with shame in order to conduct their therapeutic work effectively. The concept of shame coping thus must be taken into consideration in both research and clinical practice. However, individuals may not be aware of their own ways of coping with shame or may not be able to express it in words. Psychometrically sound measures may be more effective in assessing individuals' shame coping styles on some occasions. However, tools measuring shame and shame related concepts are still limited in Turkish culture. In fact, as yet no measure has been used in Turkey to assess shame focused coping. The Compass of Shame Scale that was developed by Elison and his colleagues (2006) measures different shame coping styles of individuals. This scale has a scenario-based nature. It was argued that scenario based scales have some advantages in measuring self-conscious emotions since these emotions occur in response to certain stimuli rather than being 
a generalized state, and scenarios ease the respondents' evaluation of their own feeling (Tangney, 1996). Thus, the purpose of the current study is to investigate the psychometric properties of the Compass of Shame Scale with the aim of measuring different ways of coping with shame.

\section{Coping with Shame}

In the case of shame, the whole self is held responsible for the occurrence of an aversive event (Tangney, 1995). Since the negative situation is attributed to the entire self, shame is regarded as an intense feeling, which impels individuals to disappear. In line with its overwhelming nature, shame is found to be related to various psychopathological symptoms. Regarding internalizing disturbances, the experience of shame shows a consistent relationship with depressive symptoms (Cândea, Matu, \& Szentágotai, 2014) and anxiety related symptomatology (Fergus, Valentiner, Mcgrath, \& Jencius, 2010). The feeling of shame was also associated with externalizing problems including intimate partner violence (Hundt \& Holohan, 2012), eating problems (Iannaccone, D’Olimpio, Cella, \& Cotrufo, 2016), and substance use (Dearing, Stuewig, \& Tangney, 2005). This divergent relation of shame with psychological problems may be explained by the ways that individuals cope with this intense emotion.

It is argued that maladaptive ways of coping with shame produce negative outcomes while effective coping contributes to more positive outcomes (Tangney, 1995). For instance, accepting one's feeling of shame was associated with decreased levels of bullying in school-aged children (Ahmed \& Braithwaite, 2004). However, sustaining constructive coping is difficult in the face of frequent and internalized cases of shame (Harper, 2011). As the feeling of shame becomes intense and frequent, individuals try to detach themselves from this feeling by using different strategies (Harper, 2011). Anger is one of the common responses that individuals show when they encounter shame (Elison, Garofalo, \& Velotti, 2014). Studies indicated that shame was associated with aggressive acts through other oriented anger (Stuewig, Tangney, Heigel, Harty, \& McCloskey, 2010; Tangney, Stuewig, \& Matinez, 2014). A retrospective study conducted with incarcerated youths revealed that detainees who do not acknowledge shame and prefer to blame others display more violent acts than those who face up to their shame (Gold, Sullivan, \& Lewis, 2011). Moreover, shame-prone criminals were more likely to commit a crime within a year of release due to their tendency to blame others (Tangney et al., 2014). From this perspective, violence may function as a protector against shame 
pervasive to and discomforting for the self (Elison et al., 2014). Moreover, the self itself may become the target of anger in people who deeply experience shame. Self-oriented anger emerges through self-critical and/or self-defeating ways in those individuals, which links shame with different kinds of psychopathologies (Gilbert et al., 2010). Shahar, Doron, and Szepsenwol (2015) found a sequential association between early memories of emotionally harsh parenting, shame, self-criticism, and social anxiety symptoms in a community sample. In fact, it was argued that self-critical responses to shame may be a defense against the flawed self which may be the reason underlying socially anxious behaviors (Shahar et al., 2015). Similarly, body shame was associated with cruel elements of self-criticism such as self-disgust and wishing to damage the self, which links the contempt of the body with binge eating problems in women (Duarte, Pinto-Gouveia, \& Ferreira, 2014). It seems that self-criticism may have a short-term relieving function in response to the more painful emotion of shame, though it initiates a shame cycle by impelling individuals to maladaptive behaviors in the long run.

There are also other responses to shame different from anger related strategies. In extreme situations such as trauma or abuse, individuals may detach away from the self as well as their emotions, which are the inseparable units of the self. For instance, shame was found to be related to dissociative behaviors in traumatized individuals and individuals having an abuse history (Platt, Luoma, \& Freyd, 2017; Talbot, Talbot, \& Tu, 2004). Otis, Marchand and Courtois (2012) even showed that dissociation occurring as a response to emotional difficulties including shame after a traumatic event predicted symptoms of posttraumatic stress disorder. How individuals deal with shame may also play a role in their characteristic way of behaving. For instance, people having narcissistic personality disorder symptoms were more likely to report shame as an aversive and unbearable emotion (Schoenleber \& Berenbaum, 2012). Thus, the motive behind their arrogant and grandiose behaviors may be to keep shame out of the self.

As the above mentioned studies indicated, coping regarding shame is important in the psychological functioning of individuals in a wide range of areas including diverse psychopathologies and dysfunctional personality traits. However, there is a scarcity of models which include shame related reactions in the literature. One of the influential models in this area was proposed by Nathanson (1992) who named the Compass of Shame. Based on his clinical work, Nathanson (1992) defined four responses given to shame which correspond to the four poles of a compass. These responses were per- 
ceived as maladaptive ways of coping with shame and are called withdrawal, attack self, attack other, and avoidance. Withdrawal and attack self are usually described as the internalizing strategies while attack other and avoidance fall into externalizing pole of the compass. In the case of withdrawal, individuals are aware of shame and try to minimize it by psychologically or physically withdrawing the self from the situation (Elison, Lennon, \& Pulos, 2006). Attack self also includes the recognition of shame but it intensifies the shameful state by directing anger toward the self (Brown, 2004). According to Elison and his colleagues (2006) the awareness of shame and self as a responsible agent of the feeling are the common grounds between withdrawal and attack self. Individuals are less likely to recognize and feel shame in the attack other condition in which one relieves the uncomfortable state by accusing others and making them feel bad about themselves. In a similar vein, individuals do not usually feel shame in avoidance but neither do they feel comfortable with the situation. They are mostly indifferent to the situation or trivialize it through jokes. As compared to other responses, avoidance is the one that mostly processes unconsciously (Elison, Lennon, \& Pulos, 2006).

Based on the model suggested by Nathanson (1992), Elison, Lennon and Pulos (2006) developed the Compass of Shame Scale (CoSS). This scale included 12 shame-inducing situations. Each situation has four responses representing four shame coping styles namely withdrawal, attack self, attack other, and avoidance. The reliability and the validity of the CoSS were tested in a variety of studies and across cultures (Elison, Pulos, \& Lennon, 2006; Schalkwijk, Stams, Dekker, Peen, \& Elison, 2016). These studies showed that the CoSS can be used as a reliable and valid measure in different contexts such as clinical and incarcerated populations. Shame coping styles showed divergent associations with many psychological outcomes in different magnitudes. In fact, withdrawal and attack self had a positive and stronger relationship with concerns of being perfect and flawless in athletes (Elison \& Partridge, 2012), and with depressive symptoms and distress (Elison, Lennon, \& Pulos, 2006) while the externalization part of shame coping styles (i.e., attack other and avoidance) were mostly related to anger and psychopathic traits such as self-indulgence, self-seeking, and disregarding characteristics (Campbell \& Elison, 2005; Elison, Pulos, \& Lennon, 2006). Coping with shame through attacking self and withdrawal also predicted poor interpersonal ties and poor rapport in therapeutic relationship, which may hinder the benefits of psychotherapy and progress of the patient in the process (Black et al., 2013). 
Socialization of gender regarding self-conscious emotions results in differences in the frequency and intensity of these emotions between men and women (Alessandri \& Lewis, 1993). For instance, even though girls and boys showed similar performance in a puzzle task, parents used more positive and specific feedback for the achievements of boys and more negative specific evaluative feedback for the failures of girls, which increased girls' propensity to experience shame (Alessandri \& Lewis, 1993). Such parental practices may result in the internalization of shame by girls and affect their stance in response to the shame. Else-Quest, Higgins, Allison and Morton (2012) found that the largest gender difference occurred in shame among self-conscious emotions and in scenario-based scales. Thus, it is important to take into consideration gender in constructs related to shame. Elison, Lennon and Pulos (2006) found that men and women differed from each other in their use of shame coping styles. That is, women got higher scores in attacking self and withdrawing while men tended to cope with shame via avoidance. However, since these differences may be sensitive to culture, it is essential to examine gender differences in different cultural contexts (Fischer, Manstead, Mosquera, \& Van Vianen, 2004).

As mentioned above, while studies on shame coping styles are abundant in international literature (e.g., Reid, Harper, \& Anderson, 2009), there have not been many studies on shame coping in Turkish literature (Cirhinlioğlu \& Güvenç, 2011). In the light of this, the first aim of this study is to adapt CoSS, which is a measurement tool that measures the ways of coping with shame, into Turkish and to test its psychometric properties. Since the CoSS factors measure maladaptive regulation of shame, its factors would associate with constructs indicating maladjustment (Elison, Lennon, \& Pulos, 2006). It is expected that withdrawal, attack self, and attack other would show significant positive correlations with the indicators of trait shame, trait anger, internalized and externalized anger, emotion regulation difficulties and depressive symptoms. These factors would negatively relate with measures of trait pride and anger control. Since pride, anger, and externalized anger are self-enhancing and self-protective emotions (Tracy \& Robins, 2004), it is expected that avoidance would have positive correlations with these constructs. The second aim of the study is to examine gender differences on the factors of CoSS. Since women were more likely to use internalizing shame coping styles (Elison, Lennon, \& Pulos, 2006), it is expected that women will use more withdrawal and attack self strategies as compared to men. 


\section{METHOD}

\section{Participants}

Data were collected from 496 participants living in different cities of Turkey (i.e., Ankara, İzmir, İstanbul). The ages of participants ranged between 18-66 ( $M=32.80, S D$ $=11.67)$. The majority was female $(N=359,72.4 \%)$ and the others were male $(N=137$, $27.6 \%$ ). Of the participants, $0.4 \%$ had a primary school certificate, $29.6 \%$ were high school graduates, $50.4 \%$ had a university degree, and $19.5 \%$ had a postgraduate degree. Among the participants, $56 \%(N=201)$ of women and $81 \%(N=111)$ of men reported to have a job. Participation was on a voluntary basis and all participants signed the informed consent form. Convenience sampling was used to access participants.

\section{Measures}

Demographic Form. This form was prepared by the researchers to get information about the age, gender, education and socioeconomic level of the participants.

Compass of Shame Scale (CoSS). The scale was developed to measure the forms of coping with shame by Elison, Lennon and Pulos (2006). It has a scenario-based nature. The CoSS consists of 12 situations which may arouse shame and participants are asked to rate four responses, placed under each situation on a 5-point Likert-type scale ranging from $1=$ Never to $5=$ Almost always (see Appendix A for the sample item). Thus, the scale consists of 48 items. These four responses represent four maladaptive coping styles of shame namely, avoidance, withdrawal, attack self, and attack other. Higher scores taken from the scale indicate higher use of maladaptive coping with shame (Elison, Lennon, \& Pulos, 2006).

For the original scale, internal consistency reliability coefficients of the factors were .89 for withdrawal, .85 for attack other, .91 for attack self, and .74 for avoidance. Test-retest reliability of the factors ranged between .75 and .85 . The scale correlated with variables measuring internalized shame, self-esteem, anger, coping and psychological symptoms (Elison, Lennon, \& Pulos, 2006).

Beck Depression Inventory (BDI). The BDI was developed by Beck et al. (1961; 1988). The instrument aims to assess depressive symptoms and contains 21 items. The scores of each item range from zero to three. Higher scores indicate higher levels of depressive symptoms. The scale was adapted to Turkish culture by Hisli (1988; 1989). The 
internal consistency coefficient of the scale was .80 and the split-half reliability was .74 (Hisli, 1989). It was used as a reliable and valid instrument. The Cronbach's alpha of BDI found in the current study was .86 (See Table 2).

Trait Shame and Guilt Scale (TSGS). The State Shame and Guilt Scale was adapted to trait scale by Rohleder et al. (2008). The TSGS consists of 15 items and three factors measuring the level of trait shame, guilt, and feelings of pride felt by the participants in the last month. Items are rated on a 5-point Likert type scale and higher scores on each factor reflect a higher level of shame, guilt, and pride. Bugay and Demir (2011) adapted the scale to Turkish and confirmed the three-factor structure of the original form. The internal consistency coefficient was .83 for shame, .81 for guilt, .87 for pride factors. The criterion validity of the scale was also tested and found to be adequate. The Cronbach's alpha values of TSGS found in the current study were .82 for trait shame and .85 for trait pride (See Table 2).

Trait Anger and Anger Expressions Inventory (TAXI). The original scale was developed by Spielberger et al. $(1983 ; 1985)$ in order to measure the state-trait anger and different anger expression styles. The scale consists of 34 items rated on a 4-point Likert type scale $(1=$ Not at all, $4=$ Defining at all). Ten items measure trait anger and 24 items measure anger expression styles. The anger expression styles include three factors namely, anger in, anger out and anger control. Higher scores on each factor reflect higher levels of frequent anger, repressed anger, externalized anger and anger control. Internal consistency coefficients of the factors were .79 for trait anger, .62 for anger in, .78 for anger out and .84 for anger control. The scale was adapted to Turkish by Ozer (1994). The Turkish form of the scale had satisfactory reliability and validity scores. The Cronbach's alpha values of TAXI found in the current study were .85 for trait anger, .74 for anger in, .82 for anger out and .85 for anger control (See Table 2).

Difficulties in Emotion Regulation Scale-Brief Form (DERS-16). The scale was developed by Bjureberg et al. (2016). It is a self-report measure assessing the aspects of emotion regulation difficulties. It consists of 16 items rated on a 5-point Likert type scale $(1=$ Almost never, 5 = Almost always). DERS-16 has five factors, namely clarity, goals, strategies, non-acceptance, and impulse. The scale was adapted to Turkish culture by Yigit and Guzey Yigit (2017). The factor structure of the original form was confirmed in the Turkish culture. Higher scores elicited from the scale indicate higher lev- 
els of difficulty in regulating emotions. The internal consistency coefficients ranged between $.78-.87$ for the factors. The Turkish version of the scale was found to be a valid and reliable measure to assess emotion regulation difficulties. The Cronbach's alpha of DERS-16 found in the current study was .90 (See Table 2).

\section{Procedure}

After obtaining permission from the authors of the CoSS, items of the scale were translated into Turkish by following a translation/back-translation procedure. The translations and back translations were made by researchers who are proficient in both languages. The ethical approval was obtained from the Review Board of the University. After that, data were collected through the online software program Qualtrics. Moreover, 78 participants filled out the questionnaires via paper-and-pencil method to assess test-retest reliability procedure with a two-week interval. For online participation, multiple responses from the same IP address was prevented. Questionnaires were completed in approximately 25 minutes. Statistical analyses were carried out via SPSS 22.0.

\section{RESULTS}

\section{Construct Validity of CoSS}

An exploratory factor analysis (EFA) was conducted to assess the structural validity of the scale. The suitability of the data for factor analysis was examined by the Kaiser-Meyer-Olkin (KMO) coefficient and the Barlett Sphericity test. A KMO value was .91 and the Barlett's Sphericity test was significant $(\chi 2(1128)=8991,38, p<.001)$. Firstly, principal component analysis was conducted without using any rotation. Results indicated 11 factors with eigenvalues greater than one. Of these 11 factors, the first four had substantially higher eigenvalues as compared to others and the scree plot test also suggested meaningful four factors. Based on the four-factor structure of the original scale, eigenvalues, and suggestion of scree plot test, principal component analysis with varimax rotation was run, forcing factors to four. 
Table 1. The Factor Structure of the Turkish Form of the CoSS

\begin{tabular}{llll}
\hline Items & Factor Loadings & $\begin{array}{l}\text { Item-Factor Communality } \\
\text { Correlations }\end{array}$ & Values \\
\cline { 2 - 4 }
\end{tabular}

1. 2. 3. 4 .

\section{Withdrawal}

22) I pull away from others.

41) I isolate myself from other people.

25) I feel like being by myself.

48) I want to be alone.

19) I wish I could avoid being noticed.

16) I keep away from other people.

9) I shrink away from others.

6) I try not to be noticed.

38) I feel like I'm shrinking.

3) I withdraw from the activity.

$35)$ I withdraw from the situation.

32*) I remove myself from the situation.

\section{Attack Other}

26) I want to point out their faults.

39) I point out their faults.

45) I push the feeling back on those who make me feel this way.

10) I blame other people for the situation.

4) I get irritated with other people.

23) I blame other people for excluding me.

13) I take it out on other people.

36) I get angry with them.

42) I get mad at people for making me feel this way.

7) I feel ill will toward the others.

20) I get mad at whoever embarrassed me.

29) I get mad at them for expecting so much.

\section{Attack Self}

28) I am aggravated by my mistakes.

12) I feel irritated with myself.

37) I get frustrated with myself for having them.

44) I get angry with myself.

21) I put myself down.

34) I repeatedly think about my imperfections.

5) I criticize myself.

2) I get mad at myself for not being good enough.

31) I get down on myself.

18) I blame myself for not being more careful.

47) I feel unworthy of being around other people.

15) I feel annoyed at myself.

\section{Avoidance}

43) I cover up the humiliation by keeping busy.

33) I soothe myself with distractions.
4.

$\begin{array}{ccc} & .69 & .62 \\ & .68 & .60 \\ & .69 & .60 \\ & .60 & .50 \\ & .57 & .45 \\ & .56 & .45 \\ & .58 & .41 \\ & .50 & .31 \\ & .53 & .48 \\ & .37 & .20 \\ .45 & .34 & .25 \\ & .24 & .26\end{array}$


14) I pretend I don't care.

$\begin{array}{lll}.56 & .41 & .32\end{array}$

40) I try not to feel bad.

$\begin{array}{lll}.55 & .34 & .35\end{array}$

17) I hide my embarrassment with a joke.

$\begin{array}{lll}.55 & .45 & .34\end{array}$

46) I disown the feeling.

$\begin{array}{lll}.51 & .39 & .31\end{array}$

30) I cover my feelings with a joke.

$\begin{array}{lll}.49 & .37 & .32\end{array}$

24) I don't let it show.

$.42 \quad .31$

11) I act more confident than I am.

$.38 \quad .29$

27) I deny there is any reason for me to feel bad.

1) I don't let it bother me.

$\begin{array}{lll}.32 & .22 & .11\end{array}$

$8 *)$ I ignore my mistakes.

.33

Variance (\%)

$\begin{array}{llll}11.83 & 11.18 & 10.57 & 6.78\end{array}$

Eigenvalues

$\begin{array}{llll}10.66 & 3.65 & 3.15 & 1.92\end{array}$

Note. $*$ represents the items excluded from further analyses. $1=$ Withdrawal, $2=$ Attack Other, $3=$ Attack Self, $4=$ Avoidance.

As seen in Table 1, the distribution of items to the factors was mostly consistent with the original scale. In the original study, item 8 was loaded to avoidance while item 32 was loaded to withdrawal. However, these two items were not loaded to their original factors in our study. Moreover, these items had the lowest correlations with their own factors in item-factor correlation analyses. Their removal improved the reliability of these particular factors. Thus, it was decided to exclude these items from further analyses. Factor loadings of the items ranged between .32 - .77. The Withdrawal factor explained $11.83 \%$ of the total variance, attack other factor accounted for $11.18 \%$, attack self factor accounted for $10.57 \%$, and avoidance factor explained $6.78 \%$ of the total variance. These four factors explained $40.37 \%$ of the total variance.

Means, standard deviations, minimum-maximum scores, and internal consistency coefficients regarding the TSGS, TAXI, DERS-16, and BDI were estimated and represented in Table 2. In order to assess the construct validity of CoSS factors, their correlations with the TSGS, TAXI, Ders-16, and BDI were examined and the results were also presented in Table 2.

As seen in Table 2, there were significant correlations between the factors of the CoSS and these scales. These correlations varied between -.30 (pride; $p<.01$ ) and .49 (anger in, $p<.01$ ) for withdrawal; -.31 (anger control, $p<.01$ ) and .46 (trait anger, $p<$ .01 ) for attack other; -.32 (pride, $p<.01$ ) and .51 (trait shame, $p<.01$ ) for attack self; .09 (anger control, $p<.05$ ) and .18 (anger in, $p<.01$ ) for avoidance. Pride and anger control had significant negative correlations with withdrawal, attack self, and attack other. Only avoidance showed a statistically significant and positive relationship with 
pride and anger control. The correlation coefficients between the CoSS factors and these scales were mostly significant in the expected direction supporting the validity of the CoSS. Correlation coefficients between the factors of the CoSS were also calculated (See Table 2.). These findings are largely similar to the findings in the original study and provided support for the construct validity of the Turkish form. In contrast to the findings of the original study, the correlation between avoidance and attack self was not significant (Elison et al., 2006).

Table 2. Descriptive Statistics and Pearson Correlation Coefficients of Study Measures and CoSS Factors

\begin{tabular}{lcccccccc}
\hline & $\boldsymbol{M}$ & $\boldsymbol{S D}$ & Min-Max & $\begin{array}{c}\text { Cronbach's } \\
\text { Alpha }\end{array}$ & Withdrawal & $\begin{array}{c}\text { Attack } \\
\text { Self }\end{array}$ & $\begin{array}{c}\text { Attack } \\
\text { Other }\end{array}$ & Avoidance \\
\hline Withdrawal & 30.44 & 8.32 & $13-52$ & .86 & - & & & \\
Attack Self & 32.07 & 9.10 & $12-60$ & .89 & $.67^{* *}$ & - & & \\
Attack Other & 24.16 & 7.31 & $12-46$ & .85 & $.42^{* *}$ & $.47^{* *}$ & - & \\
Avoidance & 29.31 & 6.30 & $13-49$ & .71 & $.14^{* *}$ & .02 & $.20^{* *}$ & - \\
Trait Shame & 8.53 & 4.20 & $5-25$ & .82 & $.44^{* *}$ & $.51^{* *}$ & $.29^{* *}$ & -.04 \\
Trait Pride & 16.85 & 4.77 & $5-25$ & .85 & $-.30^{* *}$ & $-.32^{* *}$ & $-.20^{* *}$ & $.16^{* *}$ \\
Trait Anger & 21.21 & 5.55 & $10-40$ & .85 & $.25^{* *}$ & $.30^{* *}$ & $.46^{* *}$ & $.11^{*}$ \\
Anger In & 18.15 & 4.22 & $8-32$ & .74 & $.49^{* *}$ & $.39^{* *}$ & $.34^{* *}$ & $.18^{* *}$ \\
Anger Out & 16.05 & 4.19 & $8-32$ & .82 & $.13^{* *}$ & $.22^{* *}$ & $.37^{* *}$ & .09 \\
Anger Control & 21.90 & 4.60 & $8-32$ & .85 & $-.16^{* *}$ & $-.18^{* *}$ & $-.31^{* *}$ & $.09^{*}$ \\
DERS-16 & 35.78 & 10.77 & $16-73$ & .90 & $.37^{* *}$ & $.26^{* *}$ & $.16^{* *}$ & .07 \\
BDI & 31.73 & 7.89 & $21-65$ & .86 & $.42^{* *}$ & $.47^{* *}$ & $.32^{* *}$ & -.05 \\
\hline
\end{tabular}

Note. ${ }^{*} p<.05,{ }^{* *} p<.01$. DERS-16 = Difficulties in Emotion Regulation Scale-Brief Form, BDI = Beck Depression Inventory

\section{Reliability}

Cronbach's alpha values were calculated for the internal consistency reliability of the CoSS factors. Reliability coefficients were found as .86 for withdrawal, .85 for attack other, .89 for attack self, and .71 for avoidance. Two-week test-retest reliabilities of 76 participants were .80 for withdrawal, .71 for attack other, .78 for attack self, and .75 for avoidance. Item factor correlations ranged between .24 and .69 for withdrawal, .39 and .59 for attack other, .45 and .68 for attack self, and .20 and .45 for avoidance.

\section{Gender Differences}

In order to test gender differences on the factors of the CoSS, an independent $t$-test analysis was conducted. As seen in Table 3, male/female differences were statistically significant in two factors of the CoSS. Specifically, women exhibited more attack self $(t(494)=3.12, p<.01, d=.32)$ and withdrawal $(t(494)=2.46, p<.05, d=.25)$ as com- 
pared to the men. The effect sizes (Cohen's- $d$; Cohen, 1988) for the significant differences were calculated and found to be small.

Table 3. Gender Differences for CoSS Factors

\begin{tabular}{lccccc}
\hline & \multicolumn{2}{c}{ Female $(\boldsymbol{N = 3 5 9 )}$} & \multicolumn{2}{c}{ Male $(\boldsymbol{N}=\mathbf{1 3 7})$} & \multirow{2}{*}{$\boldsymbol{t}$} \\
\cline { 2 - 5 } & $\boldsymbol{M}$ & $\boldsymbol{S D}$ & $\boldsymbol{M}$ & $\boldsymbol{S D}$ & $2.46^{*}$ \\
\hline Withdrawal & 31.01 & 8.35 & 28.96 & 8.10 & $3.12^{* *}$ \\
Attack Self & 32.86 & 9.31 & 30.03 & 8.27 & .38 \\
Attack Other & 24.23 & 7.43 & 23.96 & 7.04 & .96 \\
Avoidance & 29.49 & 6.05 & 28.85 & 6.91 & .96 \\
\hline
\end{tabular}

" $p<.05, " p<.01$

\section{DISCUSSION}

The current study aimed to investigate the psychometric properties of the Compass of Shame Scale (CoSS; Elison et al., 2006) in Turkish culture. Results supported the reliability and validity of the Turkish CoSS in assessing shame related coping mechanisms of individuals. The factors of the CoSS showed moderate to good internal consistency reliability scores. Two-week test-retest reliabilities indicated that individuals were mostly consistent in their ways of coping with shame. These results were also congruent with the findings found in the studies of the original scale (Elison, Lennon, \& Pulos, 2006) and Dutch study of the CoSS (Schalkwijk et al., 2016).

In order to test the construct validity of the Turkish CoSS, an exploratory factor analysis with varimax rotation was conducted. Based on the suggestion of the scree plot, the scale was forced to four factors. Items were mostly loaded to the factor specified in the original scale. However, one item from the avoidance factor was loaded on attack other and one from the withdrawal factor was loaded on the avoidance factor. The message that these items are supposed to convey were not congruent with the factors to which they were loaded and keeping these items under the factor to which they were loaded would damage the integrity and reliability of the scale. Thus, they were excluded in the current study. However, it can be related to a sample specific problem. Therefore, it is suggested that these two items must be analyzed in further studies.

The correlations between the factors of the Turkish CoSS, TSGS, TAXI, DERS-16, and BDI also supported the construct validity of the CoSS. The withdrawal and attack self factors mostly showed a similar pattern of correlations with these variables. Indi- 
viduals who cope with shame by escaping from the situation and/or people and by criticizing themselves were more likely to have enduring feelings of shame and anger. They also showed a tendency to suppress their anger and had difficulty in controlling it. In a similar vein, they were less likely to feel content with their being and their achievements (i.e., pride). These findings confirmed the internalizing nature of withdrawal and attack self factors. Recently, it was found that coping with shame through attacking self inclined individuals to experience frequent states of shame in both psychologically healthy and unhealthy groups (Dyer et al., 2017). In the current study, individuals using withdrawal and attacking self as ways of coping with shame also reported having difficulty in regulating their emotions. However, withdrawal shame coping had a stronger correlation with emotion regulation difficulties as compared to attack self, which may indicate that individuals using the withdrawal strategy may feel more overwhelmed in relation to their emotions. They may have more difficulty in regulating their emotions since the withdrawal strategy keeps individuals away from people who may be the sources of social support and effective solutions. The attack self coping strategy, on the other hand, may provide individuals with greater capacity to approach and handle their emotions since people can gain deference of others and hold others close to themselves through this way. Thus, despite their similarity, coping with shame via withdrawal and attacking self may be differentiated from each other regarding the psychological burden they create.

The rationale behind the attack other and avoidance coping styles is to keep shame away from the self. That is, the intensity of the shame feeling does not much diffuse to the self in these two coping strategies (Elison et al., 2006). The correlations of attack other and avoidance with the measures were mostly in line with this motive. Among four coping styles, attack other was the one showing the strongest correlation with anger and externalized anger. Surprisingly, it was also highly correlated with suppressed anger. In the attack other coping strategy, individuals may be aware of the negativity of the situation to some extent but they do not take the responsibility for the situation and thus, they keep the negativity away from the self. It may help them to reduce the intensity of shame as was suggested by its mild correlation with shame; however, they seem to have difficulty in dissolving the intense anger. This finding may suggest that people deal with their shame by converting it to anger in the attack other coping style, which may help to sustain a relatively powerful image in the eyes of others. A previous study conducted 
with athletes also revealed that athletes who are highly sensitive to making mistakes were more likely to cope with shame by attacking others (Elison \& Partridge, 2012). This finding also indicates the importance of the other's gaze in attack other coping. Avoidance of attempts to cope with shame drew a rather different portrait as compared to other coping styles. It did not have significant correlations with trait shame indicating its detachment from shame and shame related psychological states (Schalkwijk et al., 2016). Moreover, its slight but positive correlation with trait pride indicated that individuals using avoidance as a way of coping with shame had more room for positive emotionality. Elison et al. (2006) argued that the psychologically healthy outlook of the avoidance coping style found in this study and in previous studies may be misleading due to the denial inherent in this strategy. For instance, it was found that individuals having dissociative identity disorder had significantly higher levels of avoidance shame focused coping as compared the other psychological disorder groups (Dyer et al., 2017). Moreover, in contrast to previous studies (See. Elison, Lennon, \& Pulos, 2006; Schalkwijk et al., 2016) the avoidance coping style was found to be associated with anger and internalized anger in this study. This finding may indicate a cultural difference regarding anger. For instance, narcissistic power (i.e., the adaptive side of narcissism) was represented through anger and its substitutes in Turkish culture while the same construct was associated with more adaptive factors in individualistic cultures (Öngen, 2010). Thus, anger may be perceived more favorably and less problematically in Turkey.

The correlations between the CoSS factors and the BDI also provided evidence for the construct validity of the scale. According to the results, with the exception of avoidance, all factors of the CoSS were significantly associated with BDI scores of participants. That is, the more participants use coping through attacking themselves and others, as well as withdrawing themselves from the situation, the more they experience depressive states. The use of avoidant coping, on the other hand, was unrelated to depressive symptoms. This finding was consistent with the previous studies indicating that withdrawal and attack self shame focused coping were related to psychological distress in intra and interpersonal levels (Black et al., 2013; Strömsten, 2011). Attack self and withdrawal coping styles represent the internalization pole of the compass (Elison, Pulos, \& Lennon, 2006). In a similar vein, they were mostly associated with internalized outputs like depressive symptoms or low self-esteem (Yelsma, Brown, \& Elison, 2002). Attack other and avoidance coping styles are the externalization side of shame focused 
coping. Despite its externalizing nature, the attack other factor was positively related with depressive symptoms. This result was in accordance with previous studies indicating maladaptive outcomes that the aggressive coping style of shame produces (Elison, Pulos, \& Lennon, 2006; Reid et al. 2009). Avoidance, on the other hand, was not related with BDI scores. It does not eliminate the maladaptive nature avoidant coping style. It was argued that individuals who are unaware of the shame feeling or who derogate this feeling are more likely to endorse avoidance (Reid et al., 2009). Thus, the avoidance coping mechanism can be considered as a defense against negative emotionality. Thus, it may be related to psychological outcomes in which shame is processed more unconsciously such as narcissistic personality traits, addictive behaviors or psychopathic tendencies (e.g., Nyström \& Mikkelsen, 2013). In fact, a recent study indicated that the avoidance pole of shame coping was associated with fear of intimate relationships (Dorahy et al., 2013).

In terms of coping with shame, gender seems to be an important factor. The literature indicates that men are less skillful in processing shame due to several factors such as gender socialization or developmental trajectories (Wright, 1994). The current study also showed that male participants were less likely to use attack self and withdrawal strategies in which shame is accepted and sensed to some extent. It was argued that men show more counteractive reactions to shame in which they intend to structure and interpret the event differently through projection, denial or reaction formation (Wright, 1994). However, in the current study the propensity of men to avoidance coping was not confirmed which was found in previous findings. It may be largely due to the unequal distribution of gender in the current sample. Women's tendency to use internalizing shame coping methods, on the other hand, was in line with the literature findings (Elison et al., 2006; Elison \& Partridge, 2012). In Turkish women, blaming and criticizing oneself for feelings of inadequacy was one of the underlying reasons of depression (Sar1 \& Gençöz, 2016). Future studies can reach more detailed findings by focusing on the effect of gender on coping with shame since it seems that women and men tend to favor different ways of shame-coping.

The current study is the first to investigate the ways of shame coping in a collectivistic culture. Findings were mostly consistent with previous studies of the CoSS supporting its cross-cultural validation. The factorial structure of CoSS was similar to the original scale which was developed in a Western culture. This similarity may be related to 
the universality of situations that are supposed to arouse shame in the CoSS. The situations were expressed with general terms without including cultural features so that individuals can easily attribute personal meaning to them. Moreover, scenarios generated in Western cultures may be more likely to represent prototypical experiences of shame. For instance, Uskul et al. (2014) revealed that Turkish participants perceived scenarios composed by Northern American participants as prototypical of honor attacking situations while the scenarios formed by Turkish participants did not conform the prototypical image of honor attacking situations for American participants. Further research may also compare individualistic and collectivist cultures in terms of shame-coping styles.

This study has certain limitations which must be considered while evaluating the results. Firstly, the sample of the study was not equally distributed in terms of gender, as mentioned above. Future research is required to investigate the factor structure of CoSS in an equally distributed sample in order to extend the generalizability of the findings. Another limitation of the study is that variables which were chosen for the validity of the avoidance scale of the CoSS did not provide rich information about the nature and content of this coping style. Thus, associations of avoidance with different outcome variables such as narcissism, dissociation or addiction may be examined in further studies. Furthermore, the data collection tools used in the study were self-report questionnaires and this may create a limitation. Considering the unconscious processing underlying avoidance coping, implicit techniques may be used to assess its structure in future studies. Future studies that test the factor structure of the CoSS through confirmatory factor analyses would promote the reliability of these findings. Also further studies examining the psychometric properties of the CoSS in clinical populations would provide information for the clinical use of the scale. All in all, this study largely supports the CoSS as a valid and reliable measurement tool which can be used by studies conducted in Turkey.

Peer-review: Externally peer-reviewed.

Conflict of Interest: The authors have no conflict of interest to declare.

Grant Support: The authors declared that this study has received no financial support.

Hakem Değerlendirmesi: Dış bağımsız.

Çıkar Çatışması: Yazarlar çıkar çatışması bildirmemiştir.

Finansal Destek: Yazarlar bu çalışma için finansal destek almadığını beyan etmiştir. 


\section{References/Kaynakça}

Ahmed, E., \& Braithwaite, V. (2004). “What, me ashamed?": Shame management and school bullying. Journal of Research in Crime and Delinquency, 41(3), 269-294. DOI: 10.1177/0022427804266547

Alessandri, S. M., \& Lewis, M. (1993). Parental evaluation and its relation to shame and pride in young children. Sex Roles, 29(5-6), 335-343. https://doi.org/10.1007/BF00289427

Beck, A. T., Steer, R. A., \& Carbin, M.G. (1988). Psychometric properties of the Beck Depression Inventory: Twenty-five years of evaluation. Clinical Psychology Review, 8(1), 77-100. https://doi. org/10.1016/0272-7358(88)90050-5

Beck, A.T., Ward, C.H., Mendelson, M., Mock, J., \& Erbaugh, J. (1961). An inventory for measuring depression. Archives of General Psychiatry, 4(6), 561-571. doi:10.1001/archpsyc.1961.017101 20031004

Bjureberg, J., Ljótsson, B., Tull, M. T., Hedman, E., Sahlin, H., Lundh, L. G., ... Gratz, K.L. (2016). Development and validation of a brief version of the difficulties in emotion regulation scale: the DERS-16. Journal of Psychopathology and Behavioral Assessment, 38(2), 284-296. https://doi. org/10.1007/s10862-015-9514-x

Black, R. S. A., Curran, D., \& Dyer, K. F. W. (2013). The impact of shame on the therapeutic alliance and intimate relationships. Journal of Clinical Psychology, 69(6), 646-654. https://doi.org/10.1002/ jclp.21959

Boiger, M., Güngör, D., Karasawa, M., \& Mesquita, B. (2014). Defending honour, keeping face: Interpersonal affordances of anger and shame in Turkey and Japan. Cognition \& Emotion, 28(7), 1255-1269. https://doi.org/10.1080/02699931.2014.881324

Brown, J. (2004). Shame and domestic violence: Treatment perspectives for perpetrators from selfpsychology and affect theory. Sexual and Relationship Therapy, 19(1), 39-56. https://doi.org/10.1 080/14681990410001640826

Bugay, A., \& Demir, A. (2011). Psychometric properties of the Turkish version of trait shame and guilt scale. Eurasian Journal of Educational Research, 45, 17-30.http://ejer.com.tr/public/assets/ catalogs/0277663001562749551.pdf

Campbell, J.S., \& Elison, J. (2005). Shame coping styles and psychopathic personality traits. Journal of Personality Assessment, 84(1), 96-104. https://doi.org/10.1207/s15327752jpa8401_16

Cândea, D. M., Matu, S. A., \& Szentágotai, A. (2014). Individual differences in shame proneness and trait rumination as predictors of depressive symptoms. Procedia-Social Behavioural Sciences, 127, 277-281. doi: 10.1016/j.sbspro.2014.03.255

Cirhinlioğlu, F. G., \& Güvenç, G. (2011). Shame proneness, guilt proneness and psychopathology. Journal of Human Sciences, 8(1), 248-267. https://www.j-humansciences.com/ojs/index.php/IJHS/article/ view/1467/654

Cohen, J. (1988). Statistical power analysis for the behavioral sciences. Routledge.

Dearing, R. L., Stuewig, J., \& Tangney J. P. (2005). On the importance of distinguishing shame from guilt: Relations to problematic alcohol and drug use. Addictive Behaviors, 30(7), 1392-1404. https://doi.org/10.1016/j.addbeh.2005.02.002

Dorahy, M. J., Corry, M., Shannon, M., Webb, K., McDermott, B., Ryan, M., \& Dyer, K. F. (2013). Complex trauma and intimate relationships: The impact of shame, guilt and dissociation. Journal of Affective Disorders, 147(1-3), 72-79. https://doi.org/10.1016/j.jad.2012.10.010

Duarte, C., Pinto-Gouveia, J., \& Ferreira, C. (2014). Escaping from body image shame and harsh selfcriticism: Exploration of underlying mechanisms of binge eating. Eating Behaviors, 15(4), 638643. https://doi.org/10.1016/j.eatbeh.2014.08.025 
Dyer, K. F., Dorahy, M. J., Corry, M., Black, R., Matheson, L., Coles, H., ... Middleton, W. (2017). Comparing shame in clinical and nonclinical populations: Preliminary findings. Psychological Trauma: Theory, Research, Practice, and Policy, 9(2), 173-180. https://psycnet.apa.org/ doi/10.1037/tra0000158

Elison, J., Garofalo, C., \& Velotti, P. (2014). Shame and aggression: Theoretical considerations. Aggression and Violent Behaviors, 19(4), 447-453. https://doi.org/10.1016/j.avb.2014.05.002

Elison, J., Lennon, R., \& Pulos, S. (2006). Investigating the compass of shame: The development of the Compass of Shame Scale. Social Behavior and Personality: an international journal, 34(3), 221238. https://doi.org/10.2224/sbp.2006.34.3.221

Elison, J., \& Partridge, J. A. (2012). Relationships between shame-coping, fear of failure, and perfectionism in college athletes. Journal of Sport Behavior, 35(1), 19-39. https://www. researchgate.net/profile/Julie_Partridge/publication/258244675_Shame_coping_fear_of_failure_ and_perfectionism_in_college_athletes/links/00b7d52b1c54be0532000000.pdf

Elison, J., Pulos, S., \& Lennon, R. (2006). Shame-focused coping: An empirical study of the compass of shame. Social Behavior and Personality: an international journal, 34(2), 161-168. https://doi. org/10.2224/sbp.2006.34.2.161

Else-Quest, N. M., Higgins, A., Allison, C., \& Morton, L. C. (2012). Gender differences in selfconscious emotional experience: A meta-analysis. Psychological Bulletin, 138(5), 947-981. https:// doi.org/10.1037/a0027930

Fergus, T. A., Valentiner, D. P., McGrath, P. B. \& Jencius, S. (2010). Shame-and guilt-proneness: Relationships with anxiety disorder symptoms in a clinical sample. Journal of Anxiety Disorders, 24(8), 811-815. https://doi.org/10.1016/j.janxdis.2010.06.002

Fischer, A. H., Rodriguez Mosquera, P. M., Van Vianen, A. E., \& Manstead, A. S. (2004). Gender and culture differences in emotion. Emotion, 4(1), 87-94. https://doi.org/10.1037/1528-3542.4.1.87

Gilbert, P., McEwan, K., Irons, C., Bhundia, R., Christie, R., Broomhead, C., \& Rockliff, H. (2010). Self-harm in a mixed clinical population: The roles of self-criticism, shame, and social rank. British Journal of Clinical Psychology, 49(4), 563-576. https://doi.org/10.1348/014466509X479771

Gold, J., Sullivan, M. W., \& Lewis, M. (2011). The relation between abuse and violent delinquency: The conversion of shame to blame in juvenile offenders. Child Abuse \& Neglect, 35(7), 459-467. https://doi.org/10.1016/j.chiabu.2011.02.007

Hahn, W. K. (2001). The experience of shame in psychotherapy supervision. Psychotherapy: Theory, Research, Practice, Training, 38(3), 272-282. https://doi.org/10.1037/0033-3204.38.3.272

Harper, J.M. (2011). Regulating and coping with shame. In R. Trnka, K. Balcar \&M. Kuška (Eds.), Re-constructing emotional spaces: From experience to regulation, (pp. 189-206). Prague: Prague Psychosocial Press.

Hisli, N. (1988). Beck Depresyon Envanterinin gecerliligi uzerine bir calisma (A study on the validity of Beck Depression Inventory.). Psikoloji Dergisi, 6, 118-122.

Hisli, N. (1989). The validity and reliability of the Beck Depression Inventory among university students. Turkish Journal of Psychology, 7(23), 3-13.

Hundt, N. E., \& Holohan, D. R. (2012). The role of shame in distinguishing perpetrators of intimate partner violence in US veterans. Journal of Traumatic Stress, 25(2), 191-197. https://doi. org/10.1002/jts.21688

Iannaccone, M., D’Olimpio, F., Cella, S., \& Cotrufo, P. (2016). Self-esteem, body shame and eating disorder risk in obese and normal weight adolescents: A mediation model. Eating Behaviors, 21, 80-83. https://doi.org/10.1016/j.eatbeh.2015.12.010 
Lewis, M. (1995). Shame: The exposed self. New York, NY, US: Free Press.

Mosquera, R. P. M., Fischer, A. H., Manstead, A. S., \& Zaalberg, R. (2008). Attack, disapproval, or withdrawal? The role of honour in anger and shame responses to being insulted. Cognition and Emotion, 22(8), 1471-1498. https://doi.org/10.1080/02699930701822272

Nathanson, D.L. (1992). Shame and pride. New York: Norton.

Nyström, M. B. T., \& Mikkelsen, F. (2013). Psychopathy-related personality traits and shame management strategies in adolescents. Journal of Interpersonal Violence, 28(3), 519-537. https:// doi.org/10.1177/0886260512455512

Otis, C., Marchand, A. \& Courtois, F. (2012). Peritraumatic dissociation as a mediator of peritraumatic distress and PTSD: a retrospective, cross-sectional study. Journal of Trauma \& Dissociation, 13(4), 469-477. https://doi.org/10.1080/15299732.2012.670870

Ozer, A. K. (1994). Sürekli öfke (SL-ÖFKE) ve öfke ifade tarzı (OFKE-TARZ) Ölçekleri ön çalısması. Türk Psikoloji Dergisi, 31(9), 26-35.

Öngen, D.E. (2010). Relationships between narcissism and aggression among non-referred Turkish university students. Procedia-Social and Behavioral Sciences, 5, 410-415. https://doi.org/10.1016/j. sbspro.2010.07.114

Platt, M.G., Luoma, J.B. \& Freyd, J. J. (2017). Shame and dissociation in survivors of high and low betrayal trauma. Journal of Aggression, Maltreatment \& Trauma, 26(1), 34-49. https://doi.org/10. 1080/10926771.2016.1228020

Reid, R. C., Harper, J. M., \& Anderson, E. H. (2009). Coping strategies used by hypersexual patients to defend against the painful effects of shame. Clinical Psychology \& Psychotherapy: An International Journal of Theory \& Practice, 16(2), 125-138. https://doi.org/10.1002/cpp.609

Rohleder, N., Chen, E., Wolf, J. M., \& Miller, G. E. (2008). The psychobiology of trait shame in young women: Extending the social self preservation theory. Health Psychology, 27(5), 523-532. https:// psycnet.apa.org/doi/10.1037/0278-6133.27.5.523

Sarı, S., \& Gençöz, F. (2016). Shame experiences underlying depression of adult Turkish women. Qualitative Health Research, 26(8), 1102-1113. https://doi.org/10.1177\%2F1049732315579177

Schalkwijk, F., Stams, G.J., Dekker, J., Peen, J., \& Elison, J. (2016). Measuring shame regulation: Validation of the compass of shame scale. Social behavior and personality, 2016, 44(11), 17751792. https://doi.org/10.2224/sbp.2016.44.11.1775

Schoenleber, M., \& Berenbaum, H. (2012). Aversion and proneness to shame in self-and informantreported personality disorder symptoms. Personality Disorders: Theory, Research, and Treatment, 3(3), 294-304.https://psycnet.apa.org/doi/10.1037/a0025654

Shahar, B., Doron, G., \& Szepsenwol, O. (2015). Childhood maltreatment, shame-proneness and self-criticism in social anxiety disorder: A sequential mediational model. Clinical Psychology \& Psychotherapy, 22(6), 570-579. https://doi.org/10.1002/cpp.1918

Söylemez, S., Koyuncu, M., \& Amado, S. (2018). Utanç ve suçluluk duygularının bilişsel psikoloji kapsamında değerlendirilmesi. Psikoloji Çalışmaları, 38(2), 259-288. DOI: 10.26650/SP20180021

Spielberger, C. D. (1985). The experience and expression of anger: Construction and validation of an anger expression scale. Anger and hostility in cardiovascular and behavioral disorders, 5-30.

Spielberger, C. D., Jacobs, G., Russell, S. \& Crane, R. S. (1983). Assessment of anger: The state-trait anger scale. Advances in Personality Assessment, 2, 159-187.

Strömsten, L. (2011). More or less than human: the influence of shame on psychological distress. (Doctoral Dissertation). Umeå Universitet, Umeå. 
Stuewig, J., Tangney, J. P., Heigel, C., Harty, L., \& McCloskey, L. (2010). Shaming, blaming, and maiming: Functional links among the moral emotions, externalization of blame, and aggression. Journal of Research in Personality, 44(1), 91-102. https://doi.org/10.1016/j.jrp.2009.12.005

Talbot, J. A., Talbot, N. L., \& Tu, X. (2004). Shame proneness as a diathesis for dissociation in women with histories of childhood sexual abuse. Journal of Traumatic Stress: Official Publication of the International Society for Traumatic Stress Studies, 17(5), 445-448. https://doi.org/10.1023/ B:JOTS.0000048959.29766.ae

Tangney, J. P. (1995). Guilt and shame in interpersonal relationships, In J. P. Tangney \& W. Fischer (Eds.), Self-conscious emotions: the psychology of shame, guilt, embarrassment and pride (pp. 114-139). New York, Guilford Publications.

Tangney, J. P. (1996). Conceptual and methodological issues in the assessment of shame and guilt. Behaviour Research and Therapy, 34, 741-754. https://doi.org/10.1016/0005-7967(96)00034-4

Tangney, J. P., Stuewig, J., \& Martinez, A. G. (2014). Two faces of shame: The roles of shame and guilt in predicting recidivism. Psychological Science, 25(3), 799-805. https://doi. org/10.1177\%2F0956797613508790

Tangney, J. P., \& Tracy, J. L. (2012). Self-conscious emotions. In M. R. Leary \& J. P. Tangney (Eds.), Handbook of self and identity (pp. 446-478). New York, Guilford Press.

Tracy, J. L., \& Robins, R. W. (2004). Putting the Self Into Self-Conscious Emotions: A Theoretical Model. Psychological Inquiry, 15(2), 103-125. https://doi.org/10.1207/s15327965pli1502_01

Uskul, A. K., Cross, S. E., Alozkan, C., Gercek-Swing, B., Ataca, B., Gunsoy, C., \& Sunbay, Z. (2014). Emotional responses to honour situations in Turkey and northern USA. Cognition and Emotion, 28(6), 1057-1075. https://doi.org/10.1080/02699931.2013.870133

Wright, F. (1994). Men, shame, and group psychotherapy. Group, 18(4), 212-224. https://doi. org/10.1007/BF01458098

Yelsma, P., Brown, N. M., \& Elison, J. (2002). Shame-focused coping styles and their associations with self-esteem." Psychological Reports, 90(3), 1179-1189. https://doi.org/10.1177\%2F003329410 209000320.2

Yigit, İ., \& Guzey Yigit, M. (2017). Psychometric properties of Turkish version of difficulties in emotion regulation scale-Brief form (DERS-16). Current Psychology, 38(6), 1503-1511. https:// doi.org/10.1007/s12144-017-9712-7 


\section{APPENDIX A}

Sample Item

E. Toplum içinde beni utandıran bir hata yaptığımda:

12345 17. Utancımı şaka ile saklarım. (Kaçınma)

12345 18. Daha dikkatli olmadığım için kendimi suçlarım. (Kendine saldırma)

12345 19. Keşke fark edilmekten kaçınabilsem. (Geri çekilme)

12345 20. Beni utandıran her kimse ona kızarım. (Başkalarına saldırma) 
